\title{
21 YEARS AFTER INTRODUCING SENTINEL LYMPH NODE BIOPSY IN CLINICAL PRAXIS AT THE ONCOLOGY INSTITUTE OF VOJVODINA
}

\author{
Selakovic Vladimir, ${ }^{1}$ Ranisavljevic Milan, ${ }^{1,2}$ Lukic Dejan, ${ }^{1,2}$ Djuric Mladen ${ }^{1}$ \\ ${ }^{1}$ Oncology Institute of Vojvodina, Department for operative oncology, Novi Sad, Serbia \\ ${ }^{2}$ Medical faculty of Novi Sad, University of Novi Sad, Novi Sad, Serbia
}

Abstract: Introduction: Sentinel lymph node biopsy (SLNB) is a standard procedure at the Oncology Institute of Vojvodina since 1999 and during this period we have done more than 1700 biopsies. The aim of this study was to present our results in SLNB in breast cancer surgery.

Materials and methods: This retrospective study was performed at the Department for Surgical Oncology at the Vojvodina Institute of Oncology in the period from January 1999 to December 2019. The study included 1762 patients who had undergone SLNB. The mean duration of the follow-up period was 121.89 months. All patients were women with clinically T12N0-1M0 breast cancer. Preoperatively, all patients were administered dual contrast media, radiotracer, and blue dye.

Results: The majority of tumors were T1c (955 (54.18\%). The mean number of extirpated sentinel lymph nodes (SLN) in both groups was 1.84. In 199 (36.72\%) patients SLN was the only metastatic lymph node in the axilla. Micro metastases were found in 113 $(21.03 \%)$ patients. The overall diagnostic accuracy of SLNB was $96 \%$.

Conclusion: Axillary SLN can serve as a reliable predictor of negativity of other ipsilateral axillary nodes. Micro metastases in the SLN are not an indication for complete axillary lymph node dissection.

Keywords: breast cancer, sentinel lymph node, complete axillary lymph node dissection.

\section{INTRODUCTION}

Between the Halsted and Fisher concept in breast cancer treatment, almost 100 years had passed. During that period of time, it has been recognised that breast cancer biology, is a major risk factor in the determi- nation of both systematic and locoregional recurrence $(1,2)$.

Giuliano has introduced the concept of sentinel lymph node biopsy (SLNB) in breast cancer in 1997. After that, the use of complete axillary lymph node dissection (cALND) decreased from $94 \%$ to $36 \%(3,4)$.

Sentinel lymph node biopsy in breast cancer has been a standard procedure at the Oncology Institute of Vojvodina since 1999 and we have done more than 3500 biopsies.

Complete cALND is an effective method of maintaining regional control of the disease but it is associated with a significant risk of complications like lymphedema.

The aim of this study is to present our results of SLNB in breast cancer surgery at the Department of Surgical Oncology, Oncology Institute of Vojvodina.

\section{MATERIAL AND METHODS}

This retrospective study was performed at the Department for Surgical Oncology at the Oncology Institute of Vojvodina in the period from January 1999 to December 2019. The study included 1762 patients who had undergone SLNB. 909 patients were postmenopausal $(65.68 \%)$ and $763(43.30 \%)$ premenopausal with the average age being 57 years (ranging from 25 to 84). The mean duration of the follow-up period was 121.89 months (median 95, range 12-252).

The preoperative diagnosis of breast cancer was obtained after core needle biopsy and supplementary physical examination, mammography, and breast ultrasonography. Mandatory at all verified breast cancers receptor status was determinate (estrogen (ER), progesterone (PR), humane epidermal growth receptor 2 (HER 2), and proliferation factor ( $\mathrm{Ki} 67)$. 
All patients were women with clinically T1-2N0$1 \mathrm{M} 0$ breast cancer.

Preoperatively, all patients were administered dual contrast media, radiotracer (antimony sulfide nano colloid marked with technetium $1.56 \mathrm{mg} / \mathrm{ml} ; 0.3 \mathrm{mCi}$ $(11.1 \mathrm{MBq})$ - Institute for nuclear science „Vinča“. Laboratory for radioisotopes. Belgrade, Republic of Serbia) and blue dye (Blu metilene ${ }^{\circledR} 1 \%-S$. A. L. F. S. p. A. Laboratorio farmacologico ${ }^{\circledR}$ Cenate Soto, Republic of Italy)). Both contrasts were administered subcutaneously above the primary tumor and in some cases periareolar when the localisation of the primary tumor was near to the ipsilateral axilla and in cases of multifocal or multicentric tumors. The application was made with thin needles $(25 \mathrm{G})$. The radiotracer was administered 2-16 hours preoperatively, and blue dye 15 minutes before the surgery.

For the detection of the accumulated radioactivity in the sentinel lymph node (SLN), we used an intraoperative handheld (wired or Bluetooth) gamma probe $(10 \mathrm{~mm})$ to identify nodes with the greatest numerical and sound activity (Figure 1) Europrobe ${ }^{\circledR}$ 3.2, Eurorad

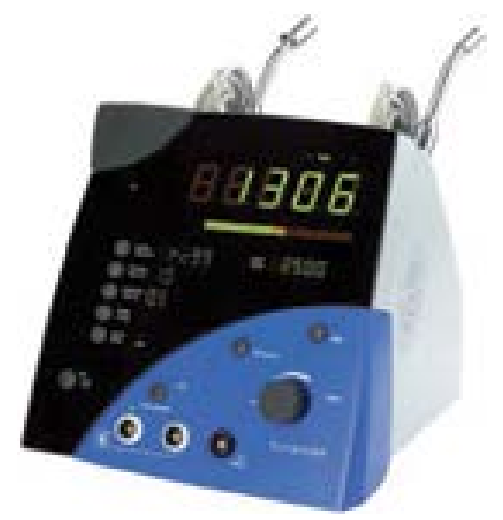

Figure 1. Gamma probe

S.A. Ekbolsheim, Republic of France. Blue dye was identified visually (Figure 2).

After putting an incision in the axilla on the place with the highest radioactivity we performed extirpation of SLN. After extirpation of SLN, breast-conserving surgery was done and the extirpation of the primary tumor. The operation was performed in this

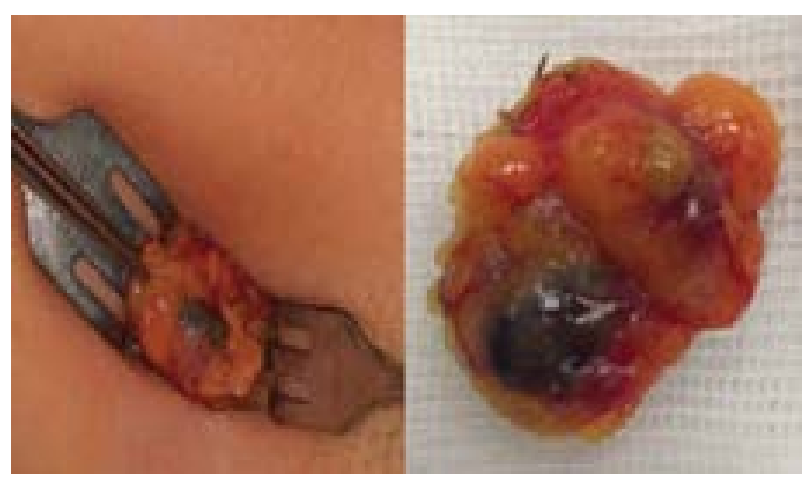

Figure 2. Colored SLN

order for the reason of not contaminating the SLN with tumor cells from the primary tumor and to obtaining false-positive results.

Immediately after the extirpation of the SLN specimen was sent for intraoperative frozen section evaluation (ex tempore). Depending on the results of the extempore SLN analysis dissection of other axillary lymph nodes was omitted or performed. In cases of micrometastases in the SLN axillary dissection was omitted.

\section{RESULTS}

Solitary tumors were found in $1662(94.33 \%)$ and multifocal tumors in $100(5.67 \%)$ patients. The most common histological type in both groups was ductal carcinoma found in $1089(61.79 \%)$ patients. The majority of tumors were T1c (955 (54.18\%). In the T2 group with positive SLN was 158 (8.96\%) and negative SLN was 199 (11.29\%) patients. SLN was negative in 1220 (69.24\%) and positive in $542(30.76 \%)$ patients (Table 1).

The mean number of extirpated SLNs in both groups (SLN positive and SLN negative) was 1.84 (median 1, range 1-6). The mean number of dissected axillary lymph nodes in the group with positive SLN on paraffin-embedded tissue sections was 18.49 (median 17, range 8-28 after cALND) (Table 2).

In 199 (36.72\%) patients SLN was the only metastatic lymph node in the axilla after cALND. In the

Table 1. Tumor characteristic in groups with positive and negative SLN

\begin{tabular}{|c|c|c|c|c|c|c|c|}
\hline \multirow{2}{*}{} & \multicolumn{2}{|c|}{ Positive SLN } & \multicolumn{2}{c|}{ Negative SLN } & \multicolumn{2}{c|}{ Total } \\
\cline { 3 - 8 } & Number & $\begin{array}{c}\text { Percent } \\
\mathbf{( \% )}\end{array}$ & Number & $\mathbf{( \% )}$ & Number & (\%) \\
\hline \multirow{2}{*}{\begin{tabular}{c} 
Tumor \\
\cline { 2 - 8 }
\end{tabular}} & Solitary & 773 & 43.87 & 889 & 50.46 & 1662 & 94.33 \\
\cline { 2 - 8 } & Multifocal & 74 & 4.21 & 26 & 1.46 & 100 & 5.67 \\
\hline \multirow{3}{*}{$\begin{array}{c}\text { Histological } \\
\text { type }\end{array}$} & Ductal & 566 & 32.13 & 523 & 29.66 & 1089 & 61.79 \\
\cline { 2 - 8 } & Lobular & 266 & 15.08 & 323 & 18.35 & 589 & 33.43 \\
\cline { 2 - 8 } & Other & 76 & 4.33 & 61 & 3.45 & 137 & 7.78 \\
\hline
\end{tabular}


Table 2. Tumor characteristics (T) in groups with positive and negative SLN

\begin{tabular}{|l|c|c|c|c|c|c|}
\hline & \multicolumn{2}{|c|}{ Positive SLN } & \multicolumn{2}{c|}{ Negative SLN } & \multicolumn{2}{c|}{ Total } \\
\cline { 2 - 7 } & Number & Percent (\%) & Number & $\mathbf{( \% )}$ & Number & (\%) \\
\hline T1a: 0.1 - 0.5 & 33 & 1.90 & 99 & 5.57 & 132 & 7.47 \\
\hline T1b:0.5 - 1.0 & 69 & 3.89 & 249 & 14.21 & 318 & 18.10 \\
\hline T1c: 1.0 - 2.0 & 282 & 16.01 & 673 & 38.17 & 955 & 54.18 \\
\hline T2: 2.0 - 3.0 & 158 & 8.96 & 199 & 11.29 & 357 & 20.25 \\
\hline Total & 542 & 30.76 & 1220 & 69.24 & 1762 & 100.00 \\
\hline
\end{tabular}

Table 3. Distant metastases according to SLN status

\begin{tabular}{|l|c|c|c|c|c|c|}
\hline \multirow{2}{*}{} & \multicolumn{2}{|c|}{ Positive SLN } & \multicolumn{2}{c|}{ Negative SLN } & \multicolumn{2}{c|}{ Total } \\
\cline { 2 - 7 } & Number & Percent (\%) & Number & $\mathbf{( \% )}$ & Number & (\%) \\
\hline Bones & 56 & 38.35 & 9 & 6.77 & 65 & 48.87 \\
\hline Liver & 32 & 24.06 & 8 & 6.02 & 40 & 30.08 \\
\hline Lungs & 21 & 15.79 & 0 & 0.00 & 21 & 15.79 \\
\hline Brain & 7 & 5.26 & 0 & 0.00 & 7 & 5.26 \\
\hline Total & 116 & 83.46 & 17 & 12.79 & 133 & 100.00 \\
\hline
\end{tabular}

group with positive SLN, micrometastases were found in $113(21.03 \%)$ patients, and in these cases, we have omitted cALND. The overall diagnostic accuracy of SNB was $96 \%$ (Table 3).

In 65 patients tumors metastasized to bones in the SLN positive and negative groups. In the SLN negative group, we did not find metastases in the lungs and brain. Metastases were found in 133 patients $(7.55 \%$ of the total number of patients). Fifteen patients died due to distant metastases in the SLN positive group during the follow-up period (Figure 3).

\section{DISCUSSION}

From the introduction of the SLNB into clinical practice in breast cancer surgery the use of cALND has decreased and the use of SLNB increased.

Histopathological classification of SLN defines three subtypes: macro metastases larger than $2 \mathrm{~mm}$, micrometastatic foci smaller than $2 \mathrm{~mm}$, and isolated tumor cells $(5,6)$. Novel studies have shown that only in cases where macrometastases are found in SLN, cALND is justified, in other cases, cALND should be omitted $(6,7)$.

The findings from the ACOSOG Z0011 study showed that at a median follow-up of 9.3 years, SLNB was non-inferior to cALND in both overall and disease-free survival, and routine use of cALND is not indicated (HR: 1.3) (5).

Some studies claimed several tumor factors indicated an early risk of recurrence, in first-line hormone-receptor negative and human epidermal growth factor receptor 2 positive and triple-negative tumors but ACOSOG Z0011 study in these cases $(5,6,8)$. But

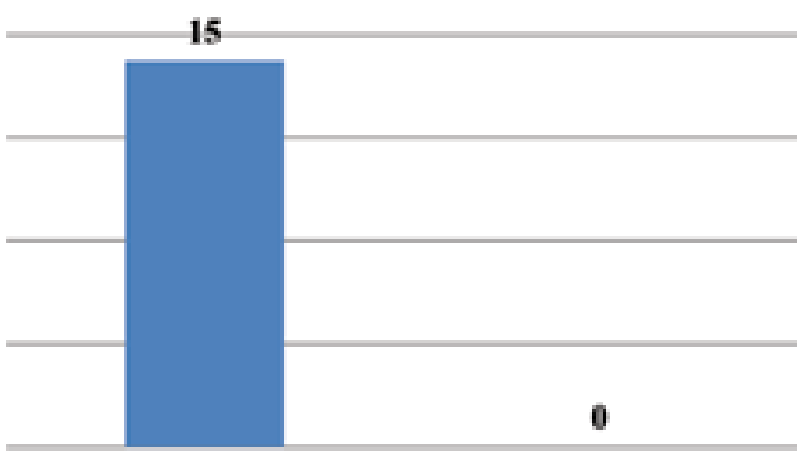

Figure 3. Death due to metastases

in this last-mentioned study, high-risk patients were treated with neoadjuvant systemic therapy and the impact of it was significant.

Age of patients is also one of the respected criteria to omit cALND (patients older than 70 years). Younger patients with HER2-positive/triple-negative breast cancer would likely become cALND (5-8).

The role of the regional nodal irradiation for patients with breast cancer remains controversial, particularly based on nodal involvement. The study from Moreno et al concluded that whole breast irradiation with regional nodal irradiation did not affect 5 -year overall survival rates for women with high-risk, early-stage breast cancer undergoing breast-conserving surgery and adjuvant chemotherapy, regardless of nodal status (9). On the opposite, the MA20 trial data showed that combined regional radiotherapy and cALND improved disease outcomes compared to standalone cALND (10).

The overall diagnostic accuracy of SNB in our study was $96 \%$ including patients with or without 
neoadjuvant chemotherapy. A meta-analysis from El Hage Chehade et al after neoadjuvant systemic therapy show a false-negative rate of $13 \%$, an SLN identification rate of $91 \%$, and a pathological complete response (pCR) of $47 \%$ (11). The pathological complete response is defined as the 'absence of vital tumor cells. The SLNB is, therefore, a viable alternative to cALND provided that at least two nodes are sampled and there is radiological evidence of response to neoadjuvant systemic therapy. The high rate of PCR suggests that ALND may be over-treatment for these node-positive patients if performed routinely and SLNB after neoadjuvant therapy can lead to the omission of ALND in a significant proportion of patients who are node-positive prior to the initiation of therapy, resulting in reduced morbidity (especially lymphedema) and hospitalisation and better quality of life for patients $(12,13)$.

Our results in SLNB are constant and in correlation with our results from 2012 in terms of identification end extirpation of SLN using booth contrast media (14).

The question is, could we omit the use of SLNB and cALND in patients with node-positive disease after neoadjuvant systemic therapy? The MARI procedure is a novel technique where the largest (positive) node in the ipsilateral axilla is marked with an iodine-125 seed which is placed underultrasound guidance. This study found that $74 \%$ of patients could have avoided cALND (15). The negative side of this procedure is the cost of using positron emission tomography, com- puterised tomography and it is not applicable in most countries around the world.

\section{CONCLUSION}

To avoid a high rate of false-negative results, SLNB should be performed using the double-contrast method (radiotracer and color). The first performed should be SLNB and then breast-conserving surgery or mastectomy to avoid false-positive results due to the transportation of cancer cells from the primary tumor to SLN. Axillary SLN can serve as a reliable predictor of negativity of other ipsilateral axillary nodes, and cALND could be omitted to avoid postoperative complications associated with this procedure. Micrometastases in the SLN (real micrometastases or groups of isolated cells) are not an indication for cALND.

\section{Abbreviations}

SLNB - sentinel lymph node biopsy

cALND - complete axillary lymph node dissection

SLN - sentinel lymph node

Conflict of Interests: The authors declare that there are no conflicts of interest related to this article.

Funding: None

\section{Licensing}

This work is licensed under a Creative Commons Attribution 4.0 International (CC BY 4.0) License.

\title{
Sažetak
}

\section{GODINA OD UVOĐENJA BIOPSIJE LIMFNOG ČVORA STRAŽARA NA INSTITUTU ZA ONKOLOGIJU VOJVODINE}

\author{
Selaković Vladimir, ${ }^{1}$ Ranisavljević Milan, ${ }^{1,2}$ Lukić Dejan, ${ }^{1,2}$ Đurić Mladen ${ }^{1}$ \\ ${ }^{1}$ Oncology institute of Vojvodina, Department for operative oncology, Novi Sad, Serbia \\ ${ }^{2}$ Medical faculty of Novi Sad, University of Novi Sad, Novi Sad, Serbia
}

Uvod: Biopsija limfnog čvora stražara je standardna procedura na Institutu za onkologiju Vojvodine od 1999. godine i do sada je urađeno više od 1700 biopsija. Cilj studije bio je da se prikažu naši rezultati u biopsiji limfnog čvora stražara u hirurgiji karcinoma dojke.

Materijal i metod: retrospektivna studija sprovedena na odeljenju operativne onkologije, Instituta za onkologiju Vojvodine u periodu od januara 1999. do decembra 2019. godine. Studija je uključila 1762 pacijenta kod kojih je bila urađena biopsija limfnog čvora stražara. Srednji period praćenja iznosio je 121,89 meseci. Svi pacijenti bili su ženskog pola i imali klinički T1-2N0$1 \mathrm{M} 0$ karcinom dojke. Preoperativno je kod svih pacijentkinja aplikovan dvojni kontrast radioobeleživač i boja.
Rezultati: Najviše tumora bilo je T1c (955 (54.18\%). Srednji broj ekstirpiranih limfnih čvorova stražara u obe grupe bio je 1,84. Kod 199 (36,72\%) limfni čvor stražar bio je jedini limfni čvor u pazuhu sa metastatskim depozitom. Mikrometastaze pronađene su kod 113 (21.03\%) pacijentkinja. Dijagnostička tačnost biopsije limfnog čvora stražara iznosila je $96 \%$.

Zaključak: Pazušni limfni čvorovi stražari služe kao siguran prediktor negativnosti ostalih limfnih čvorova ipsilateralne aksile. Prisustvo mikrometastaza u limfnom čvoru stražaru nije indikacija za disekciju ostalih limfnih čvorova pazuha.

Ključne reči: karcinom dojke, limfni čvor stražar, kompletna disekcija limfnih čvorova aksile. 


\section{REFERENCES}

1. Halsted WS. The results of radical operations for the cure of carcinoma of the breast. Ann Surg. 1907; 46(1): 1-19. doi: 10.1097/00000658-190707000-00001.

2. Fisher B, Redmond C, Poisson R, Margolese R, Wolmark N, Wickerham L, et al. Eight-year results of a randomised clinical trial comparing total mastectomy and lumpectomy with or without irradiation in the treatment of breast cancer. N Engl J Med. 1989; 320(13): 822-8. doi: 10.1056/ NEJM198903303201302. Erratum in: N Engl J Med 1994; 330(20): 1467.

3. Giuliano AE, Jones RC, Brennan M, Statman R. Sentinel lymphadenectomy in breast cancer. J Clin Oncol. 1997; 15(6): 2345-50. doi: 10.1200/JCO.1997.15.6.2345.

4. Rescigno J, Zampell JC, Axelrod D. Patterns of axillary surgical care for breast cancer in the era of sentinel lymph node biopsy. Ann Surg Oncol. 2009; 16(3): 687-96. doi: 10.1245/ s10434-008-0195-5.

5. Giuliano AE, Ballman KV, McCall L, Beitsch PD, Brennan MB, Kelemen PR, et al. Effect of axillary dissection vs. No axillary dissection on 10-Year overall survival among women with invasive breast cancer and sentinel node metastasis: The ACOSOG Z0011 (Alliance) Randomized Clinical Trial. JAMA. 2017; 318(10): 918-26. doi: 10.1001/jama.2017.11470.

6. Veronesi P, Corso G. Standard and controversies in sentinel node in breast cancer patients. Breast. 2019; 48 (suppl 1): 53-6. doi: 10.1016/S0960-9776(19)31124-5.

7. Zeitoun J, Babin G, Lebrun JF. Sentinel node and breast cancer: A state-of-the-art in 2019. Gynecol Obstet Fertil Senol. 2019; 47(6): 522-6. French. doi: 10.1016/j.gofs.2019.04.002.

8. Pan H, Gray RG, Davies C, Peto R, Bergh JCS, Pritchard KI, et al. Predictors of recurrence during years 5-14 in 46,138 women with ER+ breast cancer allocated 5 years only of endocrine therapy (ET). J Clin Oncol. 2016; 34(15): 505. doi: 10.1200/JCO.2016.34.15_suppl.505.

\section{Correspondence to/Autor za korespondenciju}

Vladimir Selaković

Put doktora Goldmana 4; 21204 Sremska Kamenica; Serbia

Phone: +381 (0)21 4805100

E-mail: selakovicvanja@gmail.com
9. Moreno AC, Lin YH, Bedrosian I, Shen Y, Stauder $\mathrm{MC}$, Smith BD, et al. Use of regional nodal irradiation and its association with survival for women with high-risk, early stage breast cancer: A National Cancer Database analysis. Adv Radiat OncoI. 2017; 2(3): 291-300. doi: 10.1016/j.adro.2017.04.008.

10. Whelan TJ, Olivotto IA, Parulekar WR, Ackerman I, Chua BH, Nabid A, et al. Regional nodal irradiation in early-stage breast cancer. N Engl J Med. 2015; 373(4): 307-16. doi: 10.1056/NEJMoa1415340.

11. El Hage Chehade H, Headon H, El Tokhy O, Heeney $\mathrm{J}$, Kasem A, et al. Is sentinel lymph node biopsy a viable alternative to complete axillary dissection following neoadjuvant chemotherapy in women with node-positive breast cancer at diagnosis? An updated meta-analysis involving 3,398 patients. Am J Surg. 2016; 212(5):969-81. doi: 10.1016/j.amjsurg.2016.07.018.

12. Kuehn T, Bauerfeind I, Fehm T, Fleige B, Hausschild M, Helms G, et al. Sentinel-lymph-node biopsy in patients with breast cancer before and after neoadjuvant chemotherapy (SENTINA): a prospective, multicentre cohort study. Lancet Oncol. 2013; 14(7): 609-18. doi: 10.1016/S1470-2045(13)70166-9.

13. Ranisavljević M, Selaković V, Lukić D, Radovanović Z, Vicko F. Impact of neoadjuvant chemotherapy on wound complications after breast surgery. Arch Oncol. 2013; 21(3-4): 105-8. doi:10.2298/AOO1304105R.

14. Golubovic A, Ranisavljevic M, Radovanovic Z, Selakovic V, Mandic A, Djilas D. Analysis of sentinel nodes biopsy in breast cancer: 12 years after introduction into clinical practice. Med Pregl. 2012; 65 (9-10): 363-7. doi: 10.2298/ MPNS1210363G.

15. Koolen BB, Donker M, Straver ME, van der Noordaa MEM, Rutgers EJT, Valdes Olmos RA et al. Combined PET-CT and axillary lymph node marking with radioactive iodine seeds (MARI procedure) for tailored axillary treatment in node-positive breast cancer after neoadjuvant therapy. Br J Surg. 2017; 104(9): 1188-96. doi: 10.1002/bjs.10555. 